\title{
ANALISIS PENINGKATAN PRODUKSI DENGAN RANCANG BANGUN ALAT PEMOTONG PADA PROSES PACKING
}

\author{
Ganda Sirait $^{1^{*}}$ dan Elva Susanti \\ ${ }^{1,2}$ Program Studi Teknik Industri, Universitas Putra Batam. \\ J1. Letjend. R. Soeprapto, Tembesi, Batam, Kepulauan Riau, Indonesia \\ *e-mail: ganda@puterabatam.ac.id
}

\begin{abstract}
Improving company productivity and efficiency in empowering human resource assessment is fulfilled to achieve company goals. one factor that can be done is the development of more effective equipment. Plastic cutting tools in the product packaging process are still simple, less efficient and less effective. The value engineering method is used as a method for selecting an alternative modification to a modified cutting tool and analyze it. At the analysis stage, two alternative modifications were modified from the improvement engine, where the initial design is used as a benchmark in performance evaluation. The result of tool design is the reduction in the number of defective products by $20.68 \%$ to $3.1 \%$ and The result of the cutting tool design is that there is an average increase in production 246 products per day.
\end{abstract}

Keywords: Cutting Tools, Quality Function Deployment.

\section{Pendahuluan}

Meningkatkan produktivitas perusahaan dan melakukan efisiensi dengan kekuatan sumber daya manusia merupakan tujuan dari perusahaan. Salah faktor yang bisa dilakukan adalah dengan mengembangkan alat atau mesin produksi yang efektif untuk menghasilkan produk yang berkualitas. Pengembangan alat dalam proses produksi adalah salah satu cara yang dilakukan perusahaan untuk mengurangi produk cacat dan untuk menghasilkan produk yang dapat diterima pasar. Kualitas produk perusahaan merupakan suatu kondisi yang dinamis dan saling berkait dengan produk, service, sumber daya, dan proses produksi, serta envirotment yang dapat memenuhi atau bahkan melebihi harapan. Berbagai upaya dilakukan agar dapat memenuhi harapan konsumen itu dan sebagai bentuk kemampuan berkompetisi di pasar global merupakan hal yang sangat kompleks. Perusahan berupaya meningkatkan kualitas produknya dengan melibatkan mengerahkan sumber daya manusia dengan mengembangkan peralatan-peralatan dan mesin produksi yang efektif. Sasaran pengembangan alat ini adalah untuk meningkatkan produksi dalam proses packing yang mengalamai banyak cacat.

\section{Landasan Teori}

Perancangan merupakan kesanggupan untuk membuat beberapa alternatif pemecahaan masalah di mana input dari hal yang akan di gunakan berasal dari hasil penemuan masalah dan pengembangannya yang di gunakan untuk mengatasi masalah (Chrisdiyanto Bayu, Nandiroh Siti, 2014). Melakukan perancangan, memerlukan fasilitas dalam berkreasi yang berfungsi sebagai alat untuk pelaksaan input data yang digunakan dalam perancangan. salah satu alat atau metode yang digunakan adalah metode quality function product.

\section{Pengertian QFD}

Konsep HoQ digunakan sebagai bahan untuk berbagai bidang industri untuk dipakai untuk analisa harapan dan teknikal sebagai syarat untuk pengembangan riset pasar dan benchmarking yang menghasilkan hasil yaitu target teknis prioritas, ada berbagai jenis matriks HoQ yang memiliki bentuk yang bermacammacam (Kasan \& Yohanes, 2017). Bentuk umum terdiri dari lima konsep utama, sebagai berikut:

1. Menentukan karakteristik produk Voice of Customer (VoC) "WHATs" berisi tentang persyaratan terstruktur yang berasal dari konsumen. 
2. Penilaian karakteristik produk, VoC berisi tentang apa saja katerisitik dari produk yang akan di rancang yang sesuai dengan relevansi yang sesuai dengan peryaratan yang terukur dari input konsumen kerangka kerja yang sering dipakai dalam mengukur kepuasan pelanggan adalah serqual dengan pendekatan menggunakan aspek dimensi yang nilai kebutuhan konsumen (Wicaksono, 2013), aspek: Tangibles merupakan penampilan yang dapat di panca indra termasuk perlengkapan, pegawai dan sarana komunikasi. Reability (keandalan) merupakan daya tahan penggunaan produk yang di pakai. Seviceability merupakan kemampuan suatu produk atau jasa yang mudah dalam perawatan dan mampu diperbaiki dan tersedia sarana perbaikan yang luas. Assurance merupakan pelayanan dari produksen yang memberikan rasa aman dan nyaman sebagai sarana jaminan yang di sediakan. Feature (keunikan) merupakan keunikan suatu produk rancangan yang tidak di miliki produk yang lain sebagai ciri khas produk tersebut. Serta Durability (daya tahan) merupakan kemampuan dalam penggunaan yang maupun terhadap sesuatu gaya yang dikenakan yang mampu bertahan meliputi material,bahan baku dan lainnya.

\section{Metode Penelitian}

Pengumpulan data dilakukan dengan cara melakukan pengamatan, wawancara kuisioner dan dokumentasi. Pengumpulan data dipersiapkan terlebih dahulu sebagai tahap persiapan untuk melakukan pengolahan data dan analisis data. Metode pengamatan: pengumpulan data yang dilakukan dengan cara melakukan sebuah kegiatan pengamatan langsung kepada objek yang sedang penelitian, seperti: proses produksi, waktu produksi, serta biaya produksi. VoC merupakan bentuk pengumpulan data dengan terlebih dahulu membuat tabel kuisioner bahwa, apa saja hal-hal yang diinginkan oleh customer menjadi suatu inputan terhadap penelitian ini. Pengolahan data adalah bagian dari tahapan dalam pengolahan data yang sudah dikumpulkan sebelumnya, merupakan upaya untuk menerjemahkan data menjadi suatu tujuan final yang dapat bermanfaat, beberapa pengujian dalam pengolahan data, seperti uji validitas untuk mengolah data kuisioner yang dapat dipercaya atau sahih, kemudian alam uji reabilitas dilakukan dalam mencari rahu bagaimana konsistensi instrument sebagai alat mengukur, sejauhmana data yang di hasilkan dapat diandalkan menjadi data penelitian yang konsisten dan dapat di lakkukan secara berulang-ulang dan dapat memberikan hasil yang sama atau konssiten atau tidak terlalu jauh hasil perbedaannya. kemudian, pengunaan uji kruskal merupakan perhitungan secara statistika (non parametrik) berbasis peringkat yang bertujuan untuk memperoleh hasil, adakah perbedaan antara dua atau lebih variabel independent terhadap variabel dependen, yang berguna untuk mengetahui taraf signifikan populasi dengan cara melakukan rangking pada masing-masing variabel data yang tujuan untuk mengetahui nilai Kruskal-Wallis atau $\mathrm{H}$ hitung, seperti yang dilakukan pada teknik uji one way ANOVA apabila normalitas data tidak terpenuhi.

1. Hipotesis uji Kruskal Wallis dilakukan untuk mengetahui hasil perbedaan antara data hasil produksi dengan menggunakan hasil rancangan alat dengan peningkatan hasil produksi tanpa menggunakan alat pemotong yang sudah dirancang dengan asumsi variabel produksi. Rumus

$K=\frac{12}{N[N+1)} \sum_{i=1} K \frac{r_{i}^{2}}{n_{i}}-3(N+1)$

Menentukan Karekteristik produk karekteristik produk atau jenis kebutuhan yang sesuai dengan keinginan pelanggan ,yang meliputi desain, komposisi, proses pemberian produk, mutu, dan lainnya.

2. Penilaian karekteristik produk.

Penelitian ini digunakan untuk dapat mengetahui bahwa, apa keinginan dari customer dan ini menjadi rangkaian dalam proses kepada produk-produk yang dihasilkan, termasuk supply material.

3. Penilaian performance

Digunakan untuk mengetahui nilai fungsi, manfaat, serta fitur hasil produk rancangan sebagai aspek pengembangan tahap berikutnya.

4. Target performance

Adalah penilaian akhir untuk mengetahui hasil rancangan alat dan melihat hubungan dengan kebutuhan secara aktual dan untuk sebagai bahan penelitian di masa depan.

a. Menentukan importance rating, tingkat kepentingan $\mathrm{VoC}$ dan di hasilkan sebagai wacana dalam perencanaan dan pengembangan produk maupun jasa

b. Analisis costomer competive evaluation, merupakan tahapan dalam menganalisis data yang telah di hasilkan untuk di lakukan evaluasi.

c. Menentukan technical requirement, adalah suatu pengembangan dari aspek kebutuhan para customer dan dasar dari hal kemampuan yang ditetapkan customer

d. Menentukan relationship matrix, yang berfungsi untuk mencari adakah hubungan yang terikat dan saling 
mempengaruhi yang merupakan hasil dari pemahaman perancang dari metode QFD yang untuk mendapat konsep teknikal.

e. Menentukan target

Planning matrix "HOWs" untuk memperoleh gambaran dari persepsi customer berdasarkan tingkah laku dari customer, yaitu memngetahui hubungan dengan berdasar pada kepentingan yang terkait atau terhubung, serta relevan adalah menjadi kriteria dan alasan untuk membuat racangan alat yang menjadi dasar bagi perusahaan.

f. Technical korelasi

Merupakan konsep matrik untk mengidentifikasi persyaratan teknis yang juga saling berhubungan, sebagai faktor pendukung dan faktor pengganggu pada suatu rancangan alat atau produk, dimana hal ini berguna sebagai materi untuk melakukan pengembangan konsep inovasi lainnya analisis competitive " technical prioritas dan targets" digunakan untuk mencari suatu rancangan alat atau produk yang menjadi prioritas dan di unggulkan dari masingmasing rancangan yang ada sebagai alat untuk mengukur kinerja suatu rancangan alat dan produk.

g. Menentukan Bobot

Bobot dapat ditentukan dari korelasi antara costumer requirement dengan technical requirement yang berasal dari kegiatan yang berlangsung, aktual, serta terhubung.

\section{Pembahasan}

Komponen Coffe maker pada produk head housing adalah bagian ini yang sering mengalami reject pada saat peprose packaging, seperti tergores hal ini membuat customer berdampak pada adanya tindakan punishment dari customer kepada perusahaan. Untuk itu penelitian mendalam dengan analisis data yang tepat perlu dilakukan. Pengumpulan data melalui penyebaran VOC memproleh hasil yang beragam dan setelah melakukan pengolahan data diketahui hasil berfungsi sebagai bahan inputan dalam penelitian ini, supaya hasil rancangan bangun dapat disesuaikan dengan kebutuhan customer. Hasil penelitian ini sangat diperlukan untuk memberikan solusi yang tepat.

Penyebaran kuisioner menggunakan seluruh responden sebanyak tiga puluh tiga orang dengan teknik pengambilan sampel jenuh, responden dilibatkan para pekerja yang bekerja shift. Setiap shift kerja didapatkan dibagi masing- masing sebelas orang. Harapan dari responden sebagai sampel bisa memberikan hasil yang sesuai dengan kebutuhan customer dalam hal perancangan alat pemotong plastik pada proses pengemasan ini dapat dicapai. Sehingga hasil rancangan beanr-benar dapat digunakan untuk menndukung proses produksi yang efisien dalam menghasilkan produksi yang optimal. Beberapa aspek dimensi untuk kebutuhan customer.

\section{Analisa metode QFD}

Analisa dengan metode HoQ dari hasil perhitungan dapat dijelaskan, dimana hasil rancangan mampu mengatasi produk reject pada kemasan, terutama reject karena tergores yang berasal dari beberapa sumber masalah selama proses pengemasan barang pada bagian pengemasan hasil produksi.

Tabel 1. Kebutuhan Customer

\begin{tabular}{cl}
\hline No & \multicolumn{1}{c}{ Aspek Kebutuhan Customer } \\
\hline 1 & $\begin{array}{l}\text { Rancang bangun alat pemotong yang rapi- } \\
\text { dan ringkas }\end{array}$ \\
2 & $\begin{array}{l}\text { Kemudahaan dalam } \\
\text { alat pemotong }\end{array}$ \\
3 & Perawatan alat pemotong yang mudah \\
4 & Penggunaan alat pemotong yang aman \\
5 & Alat pemotong yang stabil dan baik \\
6 & Alat pemotong terbuat dari material yang \\
7 & kuat \\
\end{tabular}

Tabel 2. Technical Descriptor

\begin{tabular}{cl}
\hline No & \multicolumn{1}{c}{ Technical Descriptor } \\
\hline 1 & Penggunaan alat sangat mudah / friendly \\
2 & Tenaga panas listrik arus lemah \\
3 & Pergantian wrapping yang praktis \\
4 & Pengamanan listrik yang baik \\
5 & Bahan menggunakan besi dan kayu \\
\hline
\end{tabular}

Berdasarkan tingkat kepuasan konsumen, bahwa kepuasan konsumen merupakan suatu hal yang penting dalam hubungan antara aspek kebutuhan konsumen dengan hasil responden, digunakan untuk mengetahui sejauhmana hasil rancang bangun mampu dalam mengatasi produk yang reject, khususnya proses produk saat pengemasan barang diproduksi. penulis berupaya untuk menentukan dan menjelaskan hasil rancang bangun ini diharapkan mampu mengatasi produk yang reject, dimana hasil kepuasaan konsumen mempunyai nilai kategorial tiga (3) konsumen termasuk kategori memuaskan dari hasil rancang bangun alat pemotong dalam meningkatkan produksi dengan mengurangi produk cacat pada proses pemotong plastik. Hasil dari analisis HoQ dapat menjelaskan bahwa, hasil 
rancang bangun sudah mampu mengatasi persoalan reject pada kemasan, khususnya reject tergores yang dapat berasal dari beberapa faktor yang berpotensi bermasalah, dalam hal ini fokus perbaikan adalah pada saat pengemasan produk di produksi pengemasan. Perlu beberapa tahapantahapan untuk menghasilkan rumah kualitas tersebut atau HoQ, yaitu dengan cara melakukan analisa apakah hasil rancangan alat pemotong mampu mengatasinya.

Tabel 3. House of Quality

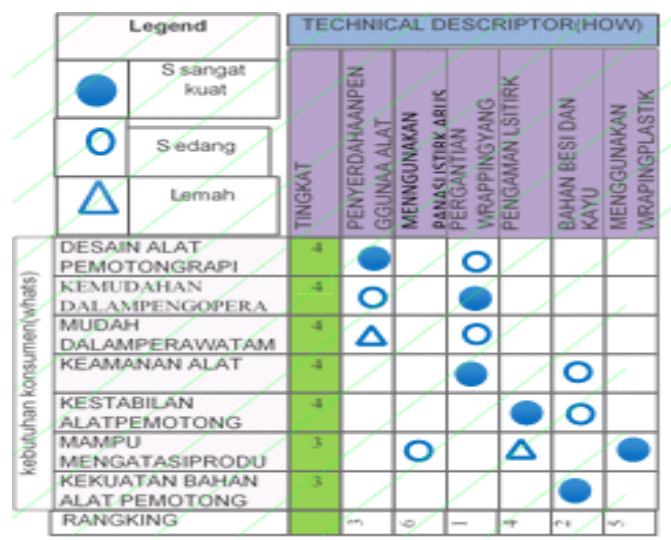

Matriks HoQ mengkonversi data dan informasi dari VoC seperti yang ditunjukkan pada tabel diatas memberikan pernyataan bahwa, konsumen menginginkan secara teknis adanya pergantian wrapping yang praktis dimana ini dapat mempengaruhi peningkatan produktivitas dan juga dapat mempengaruhi cara kerja operator karena operator produksi mampu mempersingkat waktu pergantian yang berfungsi untuk meningkatkan hasil produksi baik secara kualitas maupun kuantitas. Selain itu, hasil HoQ dapat memberikan informasi bahwa: hasil rancang bangun alat pemotong wrapping yang ringkas memdapatkan hubungan yang sangat kuat untuk penyerhanaan penggunaan alat, dan hubungan yang sedang untuk pergantian wrapping yang lebih praktis. Kemudahaan dalam mengoperasikan alat adalah sangat kuat dipengaruhi oleh pergantian wrapping yng praktis dan pengaruh yang lemah dari penyederhanaan dalam penggunaan alat pemotong, kemudahaan dalam perawatan mendapatkan pengaruh yang sedang dari pergantian wrapping yang praktis karena untuk merawat alat mudah dalam pergantian ketika plastik wrapping habis, untuk penyederhaan alat pemotong memberikan pengaruh yang lemah, dan jamiman keamanan alat di pengaruhi oleh keamanan dari bahan dasar kayu. Sedangkan untuk kemampuan alat yang dapat mengatasi produk reject, khusus reject produk tergores dipengaruhi sedang dengan pengunaan arus listrik lemah sebagai pemotong plastik dan sangat kuat dalam pengaruh oleh penggunaan wrapping plastik mengantikan plastik biasa sebagai pembungkusnya sebelumnya dan untuk kekuatan material dasar berasal dari besi di mana besi ini di lapisi isolator sebagai pengaman dari listrik bagi pengguna alat terutama operator dalam mengoperasikan alat pemotong tersebut.

\section{Analisa Perbandingan Hasil Produksi}

Perbandingan hasil produksi memberikan dampak yang signifikan dengan hasil rancang bangun alat, dilakukan dengan uji hipotesis komparatif sebagai berikut:

Ho: Tidak ada perbedaan hasil produksi dengan rancang bangun alat pemotong dalam proses packing

H1: terdapat perbedaan hasil produksi dengan rancang bangun alat pemotong dalam proses packing

Berikut ini merupakan hasil perbandingan antara penggunaan alat pemotong dan tanpa penggunaan alat pemotong.

Tabel 4. Uji Krusal wallis

\begin{tabular}{lrrr} 
Method & D & $\begin{array}{r}\text { H- } \\
\text { Value }\end{array}$ & $\begin{array}{r}\text { P- } \\
\text { Value }\end{array}$ \\
\hline $\begin{array}{l}\text { Not adjusted for } \\
\text { ties }\end{array}$ & 27 & 22.19 & 0.728 \\
$\begin{array}{l}\text { Adjusted for ties } \\
\text { F }\end{array}$ & 27 & 22.27 & 0.723 \\
\hline
\end{tabular}

The chi-square approximation may not be accurate when some sample sizes are less than 5. Berdasarkan pada perhitungan hasil seperti tabel diatas bahwa perbandingan nilai dari $\mathrm{H}$ hitung dengan $\mathrm{H}$ tabel di karena $\mathrm{H}$-value lebih besar daripada p-value maka dapat disimpulkan bahwa HO Diterima yaitu terdapat pengaruh hasil rancangan ke produksi produk Head Housing dimana dengan ditandai dengan meningkatnya produksi rata-rata perhari sebesar 246 produk perhari.

Tabel 5. Perbandingan Produksi

\begin{tabular}{cccc}
\hline No & Before & After & Subtraction \\
\hline 1 & 254 & 87 & 167 \\
2 & 264 & 84 & 180 \\
3 & 306 & 72 & 234 \\
4 & 311 & 83 & 228 \\
5 & 321 & 64 & 257 \\
6 & 334 & 54 & 280 \\
7 & 238 & 48 & 190 \\
8 & 258 & 43 & 215 \\
9 & 314 & 52 & 262 \\
10 & 286 & 49 & 237 \\
\hline
\end{tabular}




\begin{tabular}{cccc}
\hline 11 & 324 & 46 & 278 \\
12 & 312 & 44 & 268 \\
13 & 289 & 36 & 253 \\
14 & 256 & 35 & 221 \\
15 & 267 & 37 & 230 \\
16 & 314 & 32 & 282 \\
17 & 327 & 36 & 291 \\
18 & 339 & 34 & 305 \\
19 & 243 & 31 & 212 \\
20 & 257 & 30 & 227 \\
21 & 336 & 32 & 304 \\
22 & 292 & 35 & 257 \\
23 & 315 & 32 & 283 \\
24 & 326 & 31 & 295 \\
25 & 288 & 28 & 260 \\
26 & 328 & 33 & 295 \\
27 & 261 & 42 & 219 \\
28 & 326 & 41 & 285 \\
29 & 264 & 36 & 228 \\
30 & 247 & 44 & 203 \\
31 & 238 & 32 & 206 \\
32 & 245 & 54 & 191 \\
33 & 256 & 42 & 214 \\
34 & 243 & 32 & 211 \\
35 & 321 & 28 & 293 \\
36 & 324 & 25 & 299 \\
\hline Total & $\mathbf{1 0 . 4 2 4}$ & $\mathbf{1 . 5 6 4}$ & \\
\hline
\end{tabular}

\section{Daftar Referensi}

Chrisdiyanto Bayu, Nandiroh Siti, A. M. (2014). Perancangan Dan Pengembangan Meja Belajar Lipat Multifungsi. Perancangan Meja Lipat Dengan Metode QFD, 1 .

Kasan, A., \& Yohanes, A. (2017). Improvement Produk Hammock Sleeping Bag dengan Metode Quality Function Deployment (QFD). Dinamika Teknik, 10(1), 40-49.

Wicaksono, A. W. (2013). Penerapan Metode QFD Pada Rencana Pengembangan Sekolah Di SMKN 2 Yogyakarta.

Tabel 5 menunjukkan bahwa peningkatan jumlah produksi sebanyak 8.860 produk adalah merupakan hasil dari berkurangnya produk reject, pengoperasian alat yang mudah khusus, reject. Persentasi penggurangan produk cacat dari sebesar $20,68 \%$ menjadi $3,1 \%$, hasil ini di dapatkan dari hasil persentasi produksi perhari sebesar 1.400 produk per shift untuk target dalam 2 minggu menjadi 1.400 selama 36 data pengamatan adalah 50.400 produk dan untuk persentasi sebelum menggunakan hasil rancang bangun alat adalah 10.424 dibagi 50.400 adalah $20,68 \%$, dan untuk presentasi setelah penggunaan hasil rancangan alat adalah 1564 dibagi 50.400 adalah $3,1 \%$.

\section{Kesimpulan}

Hasil rancang bangun alat dapat meningkatkan hasil produksi dengan mengurangi jumlah produk reject dengan persentase sebesar 20,68 menjadi 3,1 dan dengan rancang bangun alat pemotong yang baru mampu meningkatan nilai rata-rata produksi sebanyak 246 produk per hari selama 36 kali pengambilan data pengamatan hasil produksi. 